\title{
Infinitive of German Language and its Corresponding Forms in Albanian Language
}

\author{
Brunilda Vërçani \\ 'Aleksander Xhuvani' University, Elbasan, Albania \\ English and German Language Department
}

\author{
Doi:10.5901/jesr.2013.v3n7p465
}

\begin{abstract}
Infinitive forms of verbs in different European languages, old or new, show a significant originality. This is demonstrated even by their comparison, even if it's done in only two Indo-European languages such as German and Albanian. Changes consist in the form of their occurrence, morphological features and syntactic functions. However similarities between them are not missing. They come together in the existence as morpho-syntactic categories, in the combination of verbal features with other parts of the speech, and especially in syntactic functions, because in each language almost the same functions are performed by infinitive forms, according to the principle lack of a form is compensated by another infinitive form or by another grammatical tool'. Even in the case of comparing German with Albanian language we come across the existence of an infinitive form in one language and its absence in the other language. This infinitive verbal form is the infinitive, which exists in the German language, while it does not exist in the standard Albanian language. The purpose of this article is to find the corresponding infinitive forms in Albanian language, those forms or grammatical tools which serve to compensate for the absent form in standard Albanian, as well as to express its syntactic functions, finding similarities and differences between them. This approach will be demonstrated by numerous examples extracted by the novel 'Magic Mountain', of German writer Thomas Mann, novel which has been translated even into Albanian language.
\end{abstract}

Keywords : infinitive, , syntactical functions, corresponding forms, grammatical tools

\section{Introduction}

This study aims at finding the corresponding forms of German infinitive at standard Albanian language. Since the standard Albanian language does not recognize such an unchangeable form, then in its absence it uses several grammatical tools in order to cover functions of the infinitive.

I emphasize the word standard to distinguish the northern Albanian dialect, gegërisht, which possesses analytical infinitive, that is comparable with the German infinitive and the infinitive of other European languages.

At first, the study will focus on the structure of the infinitive and its uses. Then, it will present infinitive syntactical functions and along each function there will be given the grammatical tools, which serve to cover these functions in Albanian language. Theory will be accompanied by numerous examples, extracted from literature, concretely from the novel "Magic Mountain" of Thomas Mann.

\section{The infinitive of German Language}

Nowadays German language recognizes two unchangeable forms of the verb: the infinitive and the participle form, which appears in two forms Participle I and Participle II.

The infinitive is the basic form of the verb, which is not further defined by person, number, time or mood (Duden, 2001, p.829). The infinitive is seen as a form by which a verb is given or designated or the form that the verb is presented in the vocabulary (Duden, 2005). While in Sommerfeldt / Starke grammar (Sommerfeldt / Starke, 1998) the infinitive is otherwise called a form that designates. (Subform).

The infinitive combines mainly features of verb and noun.

\subsection{Structure of the infinitive}

The infinitive is formed by adding the suffix -en to the root of the verb:

Seh-en, schlag-en, komm-en, geh-en, arbeit-en etc.

When the root of the verb ends in -el and -er, the suffix added to the root is -n: wechsel-n, lächel-n, zitter-n etc. 
Suffix $-\mathrm{n}$ is also added to the verbs sein (to be) and tun (to do)

\subsection{Infinitive uses and infinitive forms}

The infinitive of German language is often accompanied by the particle zu, which in many infinitive functions it is mandatory. In some other specific uses it is facultative and in some other cases it must not be used ( Buscha / Zoch , 1992, p.12).

The infinitive is used in various functions connected to another verb, which holds the grammatical categories of number, person, mood etc. This means it is conjugated. The infinitive itself as previously said, does not have any of these categories and as a result does not change its form according to these categories:

(1) Du sollst kommen (Ti duhet të vish / you must come)

(2) Du solltest kommen (Ti duhej të vije / you must have come)

The verb connected to the infinitive, could be a auxiliary verb, or a full verb. The infinitive could also be connected to nouns or could be used as isolated in demands:

(3) Er hatte nicht die Kraft, sich darüber Gedanken zu machen. (Ai s'kishte force të mendonte për këtë. / He did not have the strength to think about that.) pg.111

(4) ... so könnten Sie Ihre Hinterbliebenen besuchen... (...kështu ju mund të vizitoni ata që keni lënë pas.../... so you can visit those you left behind) pg. 601

(5) Er hatte etwas wichtiges zu sagen. (Ai kishte për të thënë diçka të rëndësishme. / He had to say something important)

(6) Aufstehen! (Çohuni! / Stand up)

In its infinitive uses there is no syntactic subject. The logical subject is expressed through the subject or the object (direct, indirect, with preposition) of the full conjugated verb, through an attribute or possessive pronoun of the predefined sentence.

(7)Hans Castorp glaubte, zähe Ausdünstung zu verspüren. (Hans Kastorp besonte te ndiente nje ere te rende / Hans Castorp believed to feel a tough exhalation ) . infinitive

Hans Castorp - is the subject of the conjugated verb, which simultaneously serves as a logical subject of the

The sentence could otherwise be expressed:

(7a)Hans CAstorp glaubte, dass er zähe Ausdünstung verspürt.(Hans Kastorp besonte se po ndiente nje ere te rende.)

(8) Sie bemühte sich, eine feingebildete Miene zu machen. (Ajo u perpoq te bente nje fytyre te hijshme. / She tried to make a finely formed / polite face)

Sie - the logical subject of the infinitive

otherwise expressed:

(8a) Sie bemühte sich, dass sie eine feingebildete Miene machte. (Ajo u perpoq qe te bente nje fytyre te hijshme.)

(9) Ich versprach ihm zu kommen. (I premtova të vija /I promised him to come)

Ich - subject of the verb that is conjugated, which serves at the same time as logic subject of the infinitive.

The sentence could otherwise be expressed:

(9a) Ich versprach ihm, dass ich komme (I premtova se do të vija. / I promised him that I would have come)

Ich - subject for both verbs.

(10) Der Richter bittet den Angeklagten sich zu äussern. (Gjykatësi iu lut të pandehurit të fliste. / The judge begged the defendant to speak)

Den Angeklagten - the object serves as logic subject of the infinitive.

The sentence could otherwise be expressed:

(10a)Der Richter bittet den Angeklagten, das ser (der Angeklagte) sich äussert.

(Gjykatësi iu lut të pandehurit, që të fliste. / The judge begged the defendant that he talked)

(11)Es soll mich wundernehmen, zu hören, wieviel man sich zudiktiert. pg.84

(Habitem te dëgjoj se sa kohë $i$ ke lënë vetes. / I wonder when I hear, how many time you dedicated to yourself )

mich - kundrinori qe sherben si kryefjale logjike e infinitivit

The sentence could otherwise be expressed

(11a) Es soll mich wundernehmen, dass ich höre, wieviel man sich zudiktiert.

(Çuditem qe degjoj se sa kohë $i$ ke lënë vetes) 
Note: In German the subject of the sentence could lack and in its place there comes the predefined pronoun in the role of a correlation, which is a logical subject of an infinitive form. When this form is transformed in a subordinate clause with the respective conjunctions, the subject becomes the predefined pronoun man ( Hall / Scheiner, 2001, p.174).

(12) Es ist nicht so leicht, sich einzuleben bei uns. (Nuk është aq e thjeshtë të ambjentohesh te ne. / It is not so easy settle in with us)

(12a) Es ist nicht so leicht, dass man sich bei uns einlebt. pg. 76 (Nuk është aq e thjeshtë që të ambjentohesh te ne.)

(13) Es ist überhaupt nicht leicht, Bekanntschaften zu machen. (Nuk është aspak e lehtë të krijosh njohje / It is not so easy to make friends) njohje)

(13a) Es sit überhaupt nicht leicht, dass man Bekanntschaften macht. (Nuk është aspak e lehtë, që të krijosh

In connections conjugated verb + infinitive, the distinction is made between necessary connections where the conjugated verb and the infinitive do not stand without each other, connections which are characterized by the use of the particle $\mathbf{z u}$, as well as free connections, facultative ones, which are characterized by the use of prepositions um, anstatt, ohne + particle zu by which are created, the conjunctions um...zu, - purpose conjunction, (an)statt ... zu - conjunction which expresses substitution relations, ohne zu - conjunction which expresses negation relations (without).

(14) Das benutzt sie , um die Leute zu erschrecken. (Këtë ajo përdor për të trembur njerëzit.She uses this to scare people away.) pg.75

(14a) Das benutzt sie, damit sie die Leute erschreckt. (Këtë ajo përdor që të trembënnjerëzit She uses this in order to scare people away.) emër.?

(15) Das Ergebnis war Null, ohne beim Namen genannt zu werden. pg. 874 (Rezultati ishte zero, pa u thirrur në

(15a) Das Ergebniss war Null, ohne dass es beim NAmen genannt wurde.

(16) Statt selber die Riemen zu handhaben, sa $\beta$ er auf der Terrasse und betrachtete die Boote. pg. 46 (Në vend t'i përdorte vetë rremat, $u$ ul në verandë dhe vështronte varkat)

(16a) Anstatt dass er die Riemen selber handhatte, sa $\beta$ er auf der Terrasse und betrachtete die Boote. (Në vend që t'i përdorte vetë rremat, u ul në verandë dhe vështronte varkat)

In compulsory connections conjugated verb + infinitive there are these structure characteristics to be noticed:

The particle zu which characterizes the infinitive stands directly before the infinitive or between the first part of the verb and its root at derived verbs formed with preposition or at compound verbs, the first part of which is separated from the formative topic. These verbs are called separable:

(17) Es sei schwer, das Rechte herauszufinden. pg. 426 (është e vështirë të gjesh të djathtën/

It is difficult to find the right hand.)

(18) Er veranlaßte die Vetter, auf den Zehenspitzen hinauszugehen. Pg.427(Ai I nxiti kushërinjtë të dilnin në majë të gishtave. / He pushed his cousins to go out on their toes.)

\section{Syntactic functions of the infinitive}

Infinitive in German language could perform several functions: function of the subject, could be predicate, object , attribute or could indicate circumstances of the activity (Eisenberg P. 1994) .In all its functions, the infinitive partly saves its verbal character.

\subsection{Infinitive as subject}

The infinitive performs the function of the subject in connection; full verb + infinitive, in connections that are possible only with some impersonal verbs or that are used as such. The infinitive is always accompanied by the particle zu. Subordinate clauses or infinitive forms used as nouns also appear as competitive forms of the infinitive. All infinitive forms could be used as nouns and in that case they are written in capital letters like nouns and are inflected as them.

(19) Es war wohl eine Möglichkeit, die Hüte abzunehmen. pg.442 (Ishte një mundësi e mire të hiqje kapelet. / It was a good opportunity to take off the hats.)

(20) Und mich regt es auf, solche Konfusion zu sehen. pg.531(Unë shqetësohem të shoh një konfuzion të tillë. / It bothers me to see such a confusion.)

(21) Es ist nutzlos, sich jedes Mal Gedanken darüber zu machen. (Eshtë e kotë të mendosh gjithnjë për këtë. / it 
is useless to think about this all the time.)

It has the function of an infinitive subject even when the verb conjugated, to which it is connected, is a impersonal copular verb, which together with a noun or adjective make the predicate (Buscha / Zoch , 1992). As impersonal copular verb appears before all the verb sein (jam). As a rule, the infinitive is accompanied by the particle zu. Even in this case there appear as competitive forms of the infinitive subordinate clauses and infinitive forms used as nouns.

(22) Nach Hause zu kommen, war keine Kleinigkeit. pg.350 (Të vije në shtëpi nuk ishte gjë e vogël. / Coming home was not a small thing .)

(23) Es war schwer, ihm zu raten (Ishte e vështirë ta këshilloje atë. / It was difficult to advise her) pg.420

(24) Es wäre sinnlos, die Kur vor der Zeit zu unterbrechen. pg.445 (Do të ishte pa kuptim ta ndërprisje kurën para kohe. / It would be silly to interrupt the cure earlier. )

(24a) Es ware sinnlos, dass man die Kur vor der Zeit unterbricht.

(25) Es war schwer, aufzuzählen (ishte e veshtirë të numëroje. / it was difficult counting) pg. 576

(25a) Aufzählen war schwer. (Të numeruarit ishte e veshtirë. / Counting was difficult)

(26) Es sei möglich, von Sternen zu sprechen. (Ishte e mundur, që të flisje për yjet. / It was possible speaking about the stars).

To perform the function of the subject performed by the infinitive in German language, in standard Albanian there are these corresponding language tools: subjunctive connenctive mood which is drawn by mode and in other cases as subordinate clauses. In the cases when the infinitive has taken the role of the noun, the correspondent in Albanian language it is a neutral verbal noun or a prepositional noun.

Të vije , ta këshilloje, ta ndërprisje, të numëroje - verbs in subjunctive connective mood

të numëruarit - neutral verbal noun

\subsection{Infinitive as part of the simple and compound verbal predicate}

The infinitive is used as part of the predicate in connection to a auxiliary verb.

a. The infinitive with the verb werden (become) is used to form the future tense:

(27) Er wird kommen (Ai do të vijë. / He will come)

The infinitive with the verb werden also serves to express assumption.

(28) Er wird jetzt in Berlin ankommen. (Ai do të ketë arritur tani në Berlin. / He will probably arrive now in Berlin)

b. In cases when the infinitive is connected to the auxiliary verb haben (have) it expresses necessity ( Helbig I Buscha, 1996).

In these connections the infinitive is always accompanied by the particle zu. This structure has an active meaning. When this structure is connected to a direct object, it expresses a direct possibility or permit on something:

(29) Er hatte vieles zu sagen. Pg.358 (Ai kishte shumë për të thënë. / He had much to say.)

(30) Es hatte nichts mehr zu sagen. (S'kishte më asgjë për të thënë. / It had nothing more to say.)

These structures are semantically equivalent with structures with modal verbs:

(29a) Er konnte vieles sagen (Ai mund të thoshte shumë. / He could say much)

(30a) Er konnte nichts mehr sagen (Ai s'mund të thoshte më asgjë. / He could not say anything more.)

(31) Dr. Krokowski und ...Hans CAstorp hatten miteinander zu plaudern.

(Dr. Krokovski dhe Hans Kastorp kishin për të biseduar me njëri tjetrin. / Dr. Krokowski and Hans Castorp had to talk to each other)

(31a) Dr. Krokowski und Hans Castorp mussten mit einander plaudern.

(Dr. Krokovski dhe Hans Kastorp duhej të flisnin me njëri - tjetrin. / Dr. Krokowski and Hans Castorp had to talk to each other)

The auxilary verb haben (have) appears in close connection to the infinitive of the verb tun (do): zu tun haben (have to do)

(32) Plastik, meine ich, hat mit dem Menschen zu tun pg.360 (Mendoj se plastika ka të bëjë me njeriun. / I think that plastic has to do with the person. )

The infinitive connected to the verb sein (to be) accompanied by the particle zu expresses possibility sometimes even necessity (Helbig / Buscha, 1996). These structures have passive meaning and are semantically equivalent with structures with modal verbs. merchant.)

(33) Zu sehen war nur ein ... Kaufmann pg. 396 (Për t'u parë ishte vetëm një tregtar... / To see was just a ... 
(33a) Man konnte nur ein ... Kaufmann sehen.

(34) Es ist sachlich festzustellen pg.357(Eshtë për t'u konstatuar me objektivitet. / It is objectively to ascertain.)

(34a) Man muss es sachlich feststellen

c. Apart from the auxiliary verbs, the infinitive is also connected to modal verbs müssen, sollen, dürfen, können, wollen, mögen and it is a grammatical part of the verbal compound predicate. It expresses necessity, permission, obligation, possibility, wish, purpose (Buscha / Zoch (1992). When connected to these verbs the infinitive is used without the particle zu:

(35) ... mochte er auf einem Spaziergang beginnen. (Ai donte të fillonte një shëtitje. / he liked to start a walk)

(36) Wir mögen nicht unterlassen. Fq. 884 (Nuk duam ta lëmë përgjysëm. / We do not refrain)

(37) Hans Castorp musste die Platte wechseln. Fq.886 (Hans Kastorp duhej të ndërronte pllakën e gramafonit. / Hans Castorp had to change the plate)

(38) Aber Hans Castorp konnte sich gar nicht über den vernommenen Husten beruhigen. the cough

(Por Hans Kastorp nuk mund të qetësohej aspak nga kolla që e kishte zënë. / But Hans Castorp could not soothe

d. The infinitive is also connected to verbs similar to modal verbs, but in this case is it accompanied by the particle zu.

These include verbs: brauchen, scheinen, bekommen, wissen, lassen unaccompanied by zu.

(39) Er brauchte nicht wiederzukommen . (Ai s'kishte pse të vinte përsëri. / He didn't need to come back.)

(40) Hätte Settembrini seine gewürfelten Hosen nicht mit so viel Anmut und Würde zu tragen gewusst. (Sikur Settembrini të mos dinte t'i mbante pantallonat e tij me kuadrata me kaq hijeshi dhe dinjitet. / If Settembrini wouldn't know his checkered pants to wear with so much grace and dignity)

(41) Dieser lie $\beta$ es geschehen. (Ky e la të ndodhte. / he let it happen)

(42) Es scheint doch... das Heil in der Ruhe zu finden. (Dukej sikur e gjeje shërimin te qetësia. / It seems to find salvation in the serenity.)

In Albanian language, the infinitive with the above mentioned function would again have its corresponding forms the subjunctive clause, the subordinate clause and the gerund.

Exampels

Es hatte nichts mehr zu sagen. (S'kishte më për të thënë. // It had nothing more to say)

për të thënë ( to say) - gerund

Plastik, meine ich, hat mit dem Menschen zu tun pg.360

(Plastika mendoj une ka te beje me njeriun. / I think that plastic has to do with the person)

te beje (to do) - subjunctive connective mood

Es ist sachlich festzustellen. pg.357(Eshtë për t'u konstatuar në mënyrë objektive. / It is objectively to ascertain.)

Per t'u konstatuar ( to ascertain)- gerund

(43)... wie Behrens zu sagen pflegt. pg.803 (Sic e ka zakon të thotë Berens./ sic e ka zakon qe te thote Berens / as Behrens tended to say.)

të thotë (to say) - subjunctive connective mood / qe te thote = subordinate clause

Dieser lie $\beta$ es geschehen. (Ky e la të ndodhte. / he let it happen)

të ndodhte - subjunctive connective mood

\subsection{Infinitive as object}

The infinitive with the object function is usually accompanied by the particle $\mathbf{z u}$, but there are cases when it is used even without it (Helbig / Buscha, 1996).

(44) Er war nicht gewohnt, zu philosophieren...pg.94 (Ai nuk ishte mësuar të filozofonte. / he was not accustomed to philosophize)

(45) Sie versprach, Bier zu bringen, und brachte es. pg.97 (Ajo premtoi të sillte birrë dhe e solli. / she promised bringing / to bring beer and she brought it)

(46)... dies aber zu verbergen suchte... pg.84 (... por u përpoq ta fshihte këtë... / he tried however to hide it)

As part of a sentence, the infinitive is defined by the valence of the verb on which it depends. According to its valence the subject of the infinitive verb could or could not be identical to the subject of the main verb. At verbs which are used only with subject and infinitive, the subject of the infinitive is usually identical to the subject of the main verb (Helbig / Buscha, 1996). The infinitive represents a direct object or object with preposition. 
(47) Hans Castorp beeilte sich, weiterzugehen. pg.72 (direct object)

(Hans Kastorp nxitoi të ecte më tej. / Hans Castorp hurried to move along)

(48) ... er hatte um so mehr Ursache, sich davon berührt zu fühlen... (object with preposition davon) pg.870 (... ai kishte po kaq më shumë arsye të ndihej i prekur nga kjo.../për t'u ndier I prekur nga kjo. / he had all the more reason to feel affected.)

Some verbs connected with the infinitive as object are: ablehnen (deny, throw down), anfangen (start), zweifeln (doubt), glauben (believe), vergessen (forget), sich wundern (wonder), zögern (hesitate) etc.

At verbs used with subject, infinitive and direct object, the subject of the main verb is always identical to the direct object. The infinitive usually represents an object with preposition (in some cases even a possessive object) (Helbig I Buscha , 1996).

Full verbs of this group are called verbs that require direct object. There are included: anklagen, anregen, beneiden, einladen, verpflichten, warnen, zwingen etc.

When the direct object lacks in a sentence, the subject of the infinitive is the predefined pronoun man.

At many verbs with subject, infinitive and indirect object, the subject of the infinitive is identical to the indirect object. The infinitive usually represents an indirect object (or at some verbs an object with preposition).

Here, there are included verbs that require an indirect object: abraten, befehlen, erlauben, ermöglichen, raten, versagen, zureden etc.

When the indirect object of these verbs lacks, subject of the infinitive is the predefined pronoun man

Even in the function of the object, we can see that in Albanian language the infinitive has as corresponding form the subjunctive mood and the gerund.

Hans Castorp beeilte sich, weiterzugehen. pg.72 (direct object)

(Hans Kastorp nxitoi të ecte më tej. / Hans Castorp hurried to move along)

Weiterzugehen - të ecte më tej (subjunctive mood)

... er hatte um so mehr Ursache, sich davon berührt zu fühlen... (object with preposition davon) pg. 870

(... ai kishte po kaq më shumë arsye të ndihej i prekur nga kjo.../për t'u ndier I prekur nga kjo. I

he had all the more reason to feel affected.)

zu fühlen - për t'u ndier - gerund

\subsection{Infinitive indicating circumstances of the activity.}

While the number of verbs compulsory connected to an infinitive is restricted, for the connections of a full verb with an infinitive by the conjunctions um, anstatt, ohne, + particle zu, as mention above, there are no syntactical restrictions (Eisenberg P. , 1994).

These kinds of infinitives do not depend on the valence of the verb. They appear in circumstantial function (free/facultative) and respond to specific subordinate clauses (Eisenberg P., 1994).

a. Um....zu (për të / to) clause of purpose (Finalsatz)

b. (an)statt ... zu (në vend që / instead) clause of substitution (Substitutivsatz)

c. Ohne ... zu (pa/ without) clause of manner or negatory consequential clause (Modal or Konsekutivsatz)

The infinitive of purpose could be used without the conjunction um.

Even in these cases, to the infinitive of German, in standard Albanian there are the corresponding forms: subjective clause, gerund and the subordinate clause.

(49) ..., so dass er den Kopf schräg zurücklegen musste, um ihnen ins Gesicht zu sehen ... pg. 28 them on face.)

...., kështu që ai duhej ta mbante kokën pjerrtas për t'i parë ata në fytyrë. / He had to put his head aside , to see për t'i parë (to see) - gerund

(50) Das Ergebnis war Null, ohne beim Namen genannt zu werden. pg. 874

(Rezultati ishte zero, pa u thirrur ne emër./ The result was zero without being called by name)

pa $u$ thirrur (without being called) - percjellore mohore

(51) Statt selber die Riemen zu handhaben, saß er auf der Terrasse und betrachtete die Boote. pg. 46

(Në vend t'i përdorte vetë rremat, u ul në verandë dhe vështronte varkat. / Instead itself to handle the oar he sat on the terrace and He looked at the boats)

t'i përdorte (to handle) - subjunctive clause 


\subsection{Infinitive as an attribute}

The infinitive often appears connected to a verb that could be conjugated, but in some cases it can connect even to nouns and adjectives ( Engel U., 2004). In these connections it gets the function of an attribute.

(52) Er hatte Lust zu fliehen. pg. 872 (Ai kishte deshire te arratisej. He had a desire to escape)

(53) Es ist Zeit, zu Bett zu gehen. pg.28 (Eshte koha per te shkuar ne shtrat. / It's time to go to bed)

(54)... man hatte nicht das Gefühl, sich an einer Stätte des Jammers zu befinden. pg. 66

(Nuk e kishe ndjesine e te qenit ne nje vend vuaitjesh. / they didn't feel to be located in a place of misery.)

(55) Er war nicht fähig, sich davon zuzuführen. pg. 99

(Ai nuk ishte i aftë të sigurohej nga kjo./ He was not able to supply them)

In Albanian language, this function is performed by the subjunctive clause, and the gerund with the preposition for. te arratisej (to escape) - subjunctive clause

per te shkuar (to go) - gerund

te qenit (to be located )- neutral verbal noun

\section{Conclusions}

German language recognizes two unchangeable forms of the verb: the infinitive and the participle form (I and II). German language has a very functional infinitive, while standard Albanian does not have an infinitive and a system of grammatical tools plays the role of this form.

The functions of German infinitive in standard Albanian language are performed by a whole system of tools, concretely: subjunctive clause, gerund, neutral verbal noun or prepositional noun and the subordinate clause. All these tools are used in the function of a subject, object, predicate, to indicate circumstances of the activity etc.

\section{References}

Akademia e Shkencave (1995 / 1997): „Gramatika e gjuhës shqipe“, Tiranë

Buscha / Zoch (1992): „Der Infinitiv“, Leipzig

Çeliku M. (2000): „Format e pashtjelluara të foljes në gjuhën e sotme shqipe“, Tiranë

Çeliku M. (1998): „Gramatika praktike e gjuhës shqipe“, Tiranë

Çeliku M. (2002): „Problemi i paskajores në shqipen standarde” in Republika, 29.10.2002

Demiraj Sh. (1969): "Rreth disa problemeve të paskajores në gjuhën shqipe" in SF 1

Duden (2001): „Deutsches Universalwörterbuch“, Mannheim, p.829

Duden (2005): „Die Grammatik“, Mannheim 188-192

Eisenberg P. (1994) : "Grundriss der deutschen Grammatik", Stuttgart 371-396

Engel U. (2004): "Deutsche Grammatik" München 223-228

Hall / Scheiner (2001): „Übungsgrammatik für Fortgeschrittene“, Ismaning, p.174

Helbig / Buscha (1996): "Deutsche Grammatik", Leipzig 95-109

Hentschel/Weydt (1994) : „Handbuch der deutschen Grammatik“, Berlin

Mann T.(1924/16.Auflage 2004): Der Zauberberg, Berlin

Sommerfeldt / Starke (1998) : „Grammatik der Gegenwartsprache“, Tübingen 